\title{
Post mortem on a bad deal
}

'The deal is out of the ordinary. It flies so flagrantly in the face of the Government's own privatisation policy ... and Parliament was so blatantly bypassed, that it sprouts the persistent thought that there has to be much more to it than meets the eye.'

\section{By SIR VIJAY SINGH}

A DEBT-LADEN Fiji Government's sudden decision to purchase substantial ownership of the barely solvent Daily Post for more than $\$ 500,000$ is a riddle beyond an average person's understanding.

Government already owns a radio station that claims to have "the reach of the nation". Through the Fiji Development Bank, it controls a TV station. There are a large number of privately owned newspapers and magazines. The Government has a ministry to inform the public of the affairs of the state via an extensive news media. And there is our unique "coconut wireless".

Did the Government then have, as matter of sound policy and good administration, any business to enter the newspaper business, by buying an ailing newspaper to provide a service already amply provided? The answer is clearly: NO.

Indeed, in recognition of the private sector's financial and management competence, the Government is privatising state-owned enterprises. It has sold some (for example Air Pacific, National Bank, Telecom, the Suva shipyard, etc) and more are to be sold over time.

Given this background, the irreconciliable conflict in the Government selling with one hand inherited enterprises, including some profitable monopolies, and with the other, buying into a newspaper of clouded financial viability, is far too glaring to be easily explained. 


\section{SIR VIJAY SINGH}

Given the extensive need for improvements in many services that only the Government can provide, for example to the sick and the aged, water and roads, and the anticipated pressure on its funds as a result of last year's severe drought and this year's floods, the Government's foray into the newspaper business is neither good nor responsible conduct.

Finance Minister Jim Ah Koy justified the purchase by reason of the profits the Government anticipates on sale of its shares, after it has first turned the company around to profitability. And that in itself is a million-dollar question.

Such "spin" will impress a few.

Buying into a lacklustre business, turning it around and profiting from it, is a proper function of private entrepreneurs and speculators, not of governments. In any case, there is no reason why the Government-owned FDB, which sold the shares should not have done that which the Government says it will do.

Newspapers profit from advertising, not sales. In these depressed times, businesses seek ways to reduce operating expenses. Reduction of advertising expense is easily implemented. The advent of TV has meant further sharing of corporate advertising budgets.

Given the reality of increasing number of publications vying for static, if not shrinking, corporate advertising budgets, few will share the minister's optimism. The management and accounting track record, as revealed annually by its auditors, should disabuse any normal person of the Government's expertise to turn a loss-making venture into a sought after investment.

Few will quibble with the statement attributed to Ah Koy - that the Government was "just trying to maximise a bad situation".

There may be unintended premonition in the Post printing its masthead in red ink. More than ministerial magic will be needed to turn the company into attractive investment.

If the Government truly has the scarce commercial and financial expertise it claims, it might have first fixed, say, FBC, the well-established Governmentowned radio station that generates indecent losses of public funds while William Parkinson's much later venture into broadcasting makes decent profits. There are critical differences between managing public affairs as trustee and managing one's own business.

A proper understanding of Parliament's role is very important in a democracy. The people control the executive government (the ministries) through their elected representatives. Each year, through the President's speech, the Government outlines its agenda for the parliamentary session.

26 PACIFIC JOURNALISM REVIEW 5:1 1999 
MEDIA BUY OUTS

There is no mention in the President's address of the Government going into newspaper business. Parliament control of public funds means that the Government may spend only that which it (Parliament) has approved.

As Parliament did not vote any money for that purpose, the purchase appears to have breached the Constitution and the code for financial propriety. At the very least, the minister has weakened his moral authority to demand of civil servants financial integrity and proper accounting.

"Do as I say, and not as I do" isn't an exemplary creed.

To give non-ministerial Members of Parliament a supervisory and advisory role in Government administration, the Constitution establishes sector committees "with the function of scrutinising Government administration".

The deal is out of the ordinary. It flies so flagrantly in the face of the Government's own privatisation policy - was completed with such unseemly haste, and that too on the eve of the end of this Government's life; and Parliament was so blatantly bypassed, that it sprouts the persistent thought that there has to be much more to it than meets the eye.

Sir Vijay Singh is a columnist for the Fiji Times. This article was published on 23 February 1999. 